The CLASSICAL QUARTERLY and CLASSIOAL REVIEW are the organs of the Classical Association. The QUARTERLY is published in January, April, and October (double number): the REVIEW in February, May, July, September, November, and December.

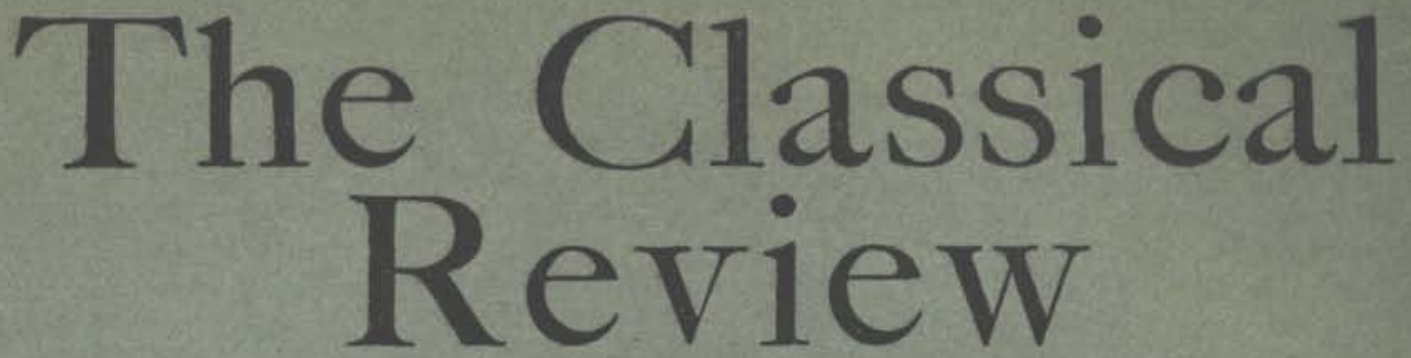

EDrroRs $\left\{\begin{array}{l}\text { E. HARRISON, M.A., Trinity College, Cambridge. } \\ \text { Prof.W. M. CALDER, LL.D., 5, Derby Road, Withington, Manchester. }\end{array}\right.$ All correspondence should be addressed to Prof. Canosen Books for review should be sent to the Publisher.

\title{
Board of Managemeat:
}

Prof J. P. DOBSON, M.A., Chairman.

Prof. A. C. OLARK, Litt.D., P.B.A. Hon. Trearsorer, I. WBIBLEY, M.A., Hon, Secreftery.

Prof, R. 8. ooNwaY, With the Chaiman, Trea.

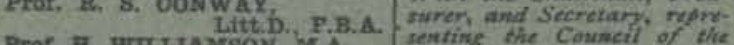
Senting the Council z. A. BARBER, M.A., representing the Oxford Pkize.

D. 8. ROBERTBOH M.A., rifresenting the Cambridge Philutegical Seciety.

With the co-operation of Prof. WM. Gardner Hask, University of Chicago;

Prof. Mauntce Hutron, University of Toronto;

Prof. T. G. Tucker, Litt.D., Melbourne.

Vol. XLII

$$
\text { JULY, } 1928
$$

No. 3

\section{CONTENTS}

Some Interpretations of Greek Plays. Mary R. Glover

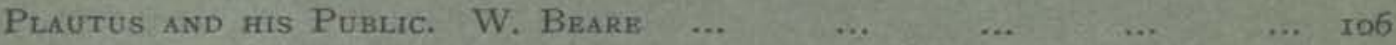

$\begin{array}{lllllllll}\text { VIRVM TE PVTABO, HOMINEM NON PVTABO. } & \text { W. T. VESEY } & \ldots & \ldots & \ldots & \text { III }\end{array}$

LONDON : JOHN MURRAY, ALBEMARLE STREET, W.

NEW YORK: G. E. STECHERT \& CO., 31-33, EAST IOTH STREET.

Price of the present Number, IS, net. Yearly Subscription, I2S. net; post free; U.S.A. S3.

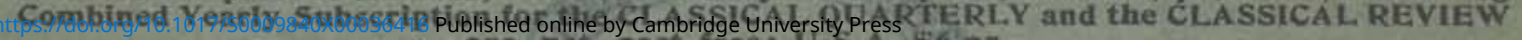
25s. met. post free; U.S.A. \$6:25. 


\title{
THE
}

\section{L A S S I C A L R E V I EW}

EDTTED BY

\section{E. HARRISON AND W. M. CALDER}

\author{
BOARD OF MANAGEMENT:
}

Prof. J. F. DOBSON, M.A. (Chairman)

\begin{abstract}
Prof. A. C. CLARK, Litt.D., F.B.A. (Hon. Treasurer) $\quad$ L. WHIBLEY, M.A. (Hon. Secretary) Prof. R. S. CONWAY, Litt.D., F.B.A. ; Prof. H. WILliamSON, M.A. ;

E. A. BARBER, M.A. ; Prof. D. S. ROBERTSON, M.A.
\end{abstract}

With the co.operation of Prof. E. K. RAND, Harvard University, and Prov.

W. RITCHIE, University of Cape Town.

\section{VOLUME XLII.}

PUBLISHED FOR THE CLASSICAL ASSOCIATION

\section{LONDON}

JOHN MURRAY, ALBEMARLE STREET, W. NEW YORK

G. E. STECHERT \& CO., 3I-33, EAST IOTH:STREET 1928 


\section{TABLE OF CONTENTS}

Notes and News.

Composition. A. L. PEck .

Note on Song-birds in Greek Literature. J. T. ALLEN

A Note on the New Callimachus. A. S. Hunt. Notes on the Nicomachean Ethics. H. RACKHAM . Oxyrhynchus Papyri XVII. 2078. A. E. Hoos-

Horace, Satires $\dot{I .4} 6$ ff. $\dot{\text { W. M. EDWARDS }}$

A New Roman Governor of Provincia Britannia.

D. Atrinson

How to Catch Cuttlefish. D'Arcy W. Thompson The Magical Vine of Nysa and the Dionysiac Wine Miracle. W. R. Halliday.

Aeschylus, Agamemnon 1285 . M. E. J. TAYLOR. Plautus, M.G. 843. W. BeARE .

Aquilo, the Black Wind. W. M. Lindsay

\section{Reviews :}

Homer's Ithaka (Rodd), A. Shewan, 2I; The History and Civilisation of Ancient Megara, I. (Highbarger), H. T. WADE-GERY, 22 ; 'Aגkalov Me $\lambda \eta$ (Lobel), C. M. Bowra, 23; Études sur la Tragédie Grecque dans ses Rapports avec la Céramique (Séchan). Le Dévouement d'Alceste (Id.), A. W. Pickard-Cambridge, $25 ; A$ ristophanes Lysistrate (Wilamowitz-Moellendorff).

Version. J. A. NAIRN

Notes and News.

The Rhythms of Pindar. H. D. F. KIтro :

Two Passages in the Agamemnon. H.S. DAwson

Notes on the Philoctetes of Sophocles. S. K. JoHNSON .

Aristophanes' Pax 695-699. D, L. Drew .

Note on alvirtertal, Plato, Apology, 27A, $21 \mathrm{~B}$. S. E. BAssert .

A Greek Epigram. ]. D. BeazLEY

Vergil, Georgics II. 277. F. H. SANDBACH .

Juvenal VIII. 241 . D. S. ROBERTSON

The Fitzwilliam Goddess. A. J. Evans .

Ascra. O. Davies

Terence, Phorm. 330 . W. M. LINDSAY

Terence, Eun. 230. W. M. Lindsay.

Lucretius II. 515-6. L. S. Hearnshaw

Was Persius a 'Micher'? J. TAIB.

Reviews :

Some Verse Translations, A. S. Owen, 64 ; Some Class-books, H. Listre, 67; Greek and Roman Folklove (Halliday), H. J. Rose, 69; Books on Ancient Sculpture, A. J. B. WACE,

Some Interpretations of Greek Plays. Mary R. Glover

Plautus and his Public $\dot{W}$. • .
No. 1.

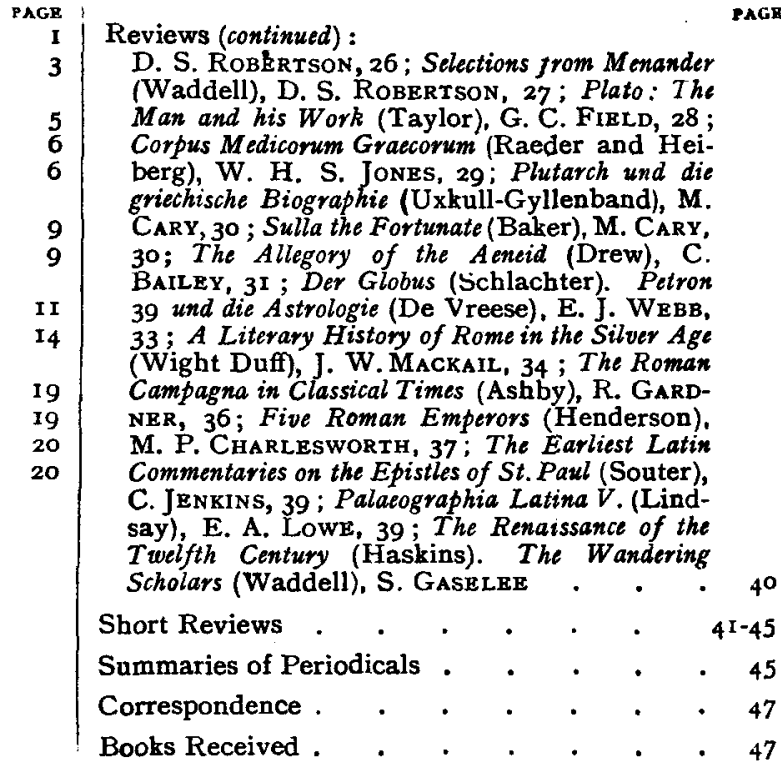

No. 2.

49
49
51
53
55
56
58
58
59
60
61
62
62
63
63
63

Reviews (continued) :

70; Art in Greece (de Ridder and Deonna), E. S. Forster, 72; 'Sixth and Fifth Century Pottery from Rhitsona (Ure), E. S. FORSTER, 73: Agonistic Features of Local Greek Festivals (Ringwood), E. N. GARDINER, 74 ; Hellenistic Civilisation (Tarn), A. W. Goмme, 75 ; Fragmenta Poctarum Latinorum (Morel), A. E. Housman, 77; A History of Egypt under the Ptolemaic Iynnasty (Bevan), W. W. TARN, 79; The Iron Age in Italy (Randall-MacIver), J. E. PeET, 80; Virgil's Secret and other Plays (Macnaghten), J. W. MackaIL, 81; Le Monde Romain (Chapot), D. ArkInson, 82 ; Municipal Administration in the Roman Empire (Abbott and Johnson), D. Atrinson, 83; Index to the 'Pharsalia' of Lucan (Mooney). W. B. ANDERSON . . . . . . . 84 Short Reviews . . . . . . 85-9I

Summaries of Periodicals . . . . . 92

Correspondence . . . . . . . . 94

Books Received . . . . . . . 94

No. 3.

$97 \begin{gathered}\text { Virum te putabo, hominem non putabo. W. T. } \\ \text { VesEY }\end{gathered}$ I I I

No. 4.

Notes and News

Three Notes on Aeschylus, Prometheus Vinctus.

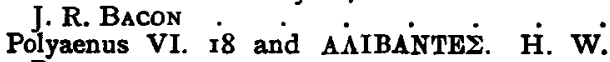
PARKE

II

The

The First Editor of Lucretius. A. E. Housman 122 Virgil, Eclogue IV. I8-20. E. I. RoBsoN . . 123 Horace's Tiburtine Villa. G. H. HallaM . 125 Two Parallels. A. Cameron . . . . 127

r2o Latin hinnuleus again. J. WhaтмобGH : : 127 
Reviews :

A Study of the 'Iliad' in Translation (Clark), J. T. ShePPARD, I 28; Lyra Graeca, III. (Edmonds), J. F. DoBson, I28; A ristophanes, Dio Vögel (Kock-Schroeder), W. RenNie, 129 ; Some Greek Texts and Translations, E. HARRISON, 13o; New Papyri, C. M. Bowra, 13I ; Hellenic Civilisation (Croiset), P. N. URE, 133 The Documentary Sources of Greek History (Cary), E. M. WALKER, I 34 ; Lucretiana, C. BAILEX, 135; The Architect of the Roman Empire (Rice Holmes), G. H. Strevenson, 137; Neue Wege zur Antike, r926-7, 2; Il Problema della Origi.
PAGE

Reviews (continued) : nalità Romana (Castiglioni), J. WIGHT DOFF, 138; Tito Livio $X X X V I I$. (de Regibus), S. K. JohnSON, 140; Slavery in the Roman Empire (Barrow), M. Cary, $\mathrm{I}_{4} \mathrm{I}$; Roman Coins (Mattingly), J. TOYNBEE, 142 ; The Soul of Grammar (Sonnenschein), H, Williamson

Short Reviews . • • • . . 145-154

Summaries of Periodicals . . . . . I54

Correspondence . . . . . . . 157

Books Received . . . . . . . 157

No. 5.

Kybele and Gallos in the Hittite Texts. A. H. The Women's Quarters in the Palace of Odysseus. J. M. WYLLIE

Herodes II. 6-8. A. D. KNox .

Horace, Odes IV. I 2. C. M. Bowra. .

Was Persius not a 'micher'? G. B. A. FletCHER

From The Yeomen of the Guard. J. F. C. .

Thucydides VI. 64. 1. H. J. Rose . . .

Plato, Timaeus 37c. EDwy Bevan . Athenian Citizen? H. W. Parke .

Note on Theocritus X. $26 \mathrm{ff}$. M. E. DickER

The River of Tears. H. J. Rose I

A New Title of Fortuna? H. J. Rose . . I7I

Note on Metellus Celer's Letter to Cicero. R. G. C. Levens

Juvenal III. 186-9. J. O. Thomson : : :

Livy XLV. I2 W R HALLIDAY

Reviews:

The Age of the Gods (Dawson). A Short History of Civilization (Thorndike). J. L. MYrES, I72 ; $A$ History of the Ancient World (Rostovtzeff), W. M. CALDER, 174; Color in Homer and in Ancient Art (Wallace), M. Platnader, I75; The Ithaca of the Odyssey (Burrage), A. ShewaN, 177 ; Pindar: Pythian Odes (Wade-Gery and Bowra), D. S. Robertson, 177; A ischylos und das Handeln im Drama (Snell), J. T. SHePPARD, 178; Greek Philosophy before Plato (Scoon),

Notes and News.

Some Aspects of Dramatic Irony in Sophoclean Tragedy. S. K. JoHNSON

The Priority of the Mercator. W. Beire:

Lucretius V. I34I-9. R. B. ONIANS .

Tacitus, Annals IV. I2. E. C. MARchanr.

Horace, Ep. 1. 6, 5.8. W. S. MAGUINNESS

Charito I. 3, 5. R. M. RatrenbURY.

Reviews (continued):

A. E. TAYLOR, 180; Struktur und Charakter des Platonischen Phaidros (Diesendruck), R. HACKFORTH, I8I ; Hellenica Oxyrhynchia (Kalinka), E. M. WALKER, 182; The Cambridge Ancient History, V., VI., A. W. Gомме, I83; Isaeus (Forster). Eschine I. (Martin and de Bude). Isocrates, De Pace and Philippus (Laistner), J. F. DoBson, 189; A Working Bibliography of Greek Law (Calhoun and Delamere), M. N. ToD, I91; The Argonautica of Apollonius Rhodius, Book III. (Gillies), J. H. E. Crees, IgI ; Plutarchi Vitae Parallelae, III., ii. (Lindskog and Ziegler), E. HARrison, I92; Some Questions of Musical Theory, III., IV. (Perrett), J. F. ModNTFORD, I93; Later Greek Religion (Bevan), A. D. Nock, 194 ; Horace: Satires, Epistles and Ars Poetica (Fairclough), W. W. GRUNDY, 194 ; Catullus and Horace (Frank). The Rome of Horace (Ingersoll), H. E. BotLer, I96;Albii Tibulli Aliorumque Carminum Libri IV. (Calonghi), H. Stewarr, I97; La Technique des Discours dans Salluste, Tite Live et Tacite (Ullmann), S. K. JoHNSON, 198 ; Die antiken Grundlagen der frühmittelalterlichen Privaturkunde (Steinacker). H. I. BELL, I99 ; Some Classbooks, W. G. WADDELL

Short Reviews . . . . . . 203-206

Summaries of Periodicals . . . . . 206

Books Received . . . . . . . . 207

No. 6.

209 Reviews (continued) :

(Knorringa), K. M. T. Chrimes, 228 ; Introduction to the Study of the Greek Dialects (Buck), S. G. CAMPBell, 229; Die Griechisch-Orientalische Romanliteratur (Kerényi), D. S. RoBERTSON, 230 ; Epochs of Greck and Roman Biography (Stuart), M. CARY, 232 ; Lateinische Grammatik, I., II. (Stolz-Schmalz, etc.), J. FraSER, 232 ; The Etruscars (Randall-MacIver), R. S. CoNwaY, 233; Cicero: Pro Lege Manilia, etc. (Hodge), G. B. A. Fletcher, 236; Die Geschichte des Sallusttextes im Altertum (Höhne) S. K. Johnson, 236; Statius (Mozley), H. STEWART, 237 ; Les Antiquités romaines de la Rhénanie (Colin), R. G. Collingwood . . $23^{8}$ Short Reviews . • . • . . 238-245 Summaries of Periodicals . . . . . 245 Books Received . . . . . . . 246 Index . . . . . . . . . 247 